\title{
Transformational administration as form of innovative development of the construction organization
}

\author{
Svetlana Grigoreva* \\ Moscow State University of Civil Engineering, Yaroslavskoe shosse, 26, Moscow, 129337, Russia
}

\begin{abstract}
In article the theory of transformational administration as a form of innovative development of the construction organization is offered. An object, a subject, the principles of the theory are opened. Such forms of transformational administration as harmonious administration, risk administration, IT-administration are considered. The architecture of a management system is provided by strategic stability of the construction organization.
\end{abstract}

\section{Introduction}

In the conditions of transformation of an economic environment of one of the key strategy of the Government of the Russian Federation sustainable development is the construction organizations. Factors of internal and external origin which can render both positive, and negative impact exert huge impact on activities of the construction organization, level of its strategic stability. All above-mentioned is a basis of innovative development of the organization and causes need of studying of a possibility of management of strategic stability of the construction organization. Intensive development of a construction industry leads to emergence of new concepts, management theories [1,2,5-8, 11-13]. For ensuring innovative development of the construction organization system development management of effective use of strategic resources of the organization, management of results of strategic stability taking into account risks of economic activity and innovation management is necessary for increase in level of strategic stability of the organization. Managements of strategic stability of the construction organization and traditional management on the one hand are in close interrelation as they have an overall objective of management - effective functioning of the construction organization, and on the other hand management of strategic stability of the construction organization focuses attention to organization development. Now there is enough developments in the field of traditional management [3]. We will consider transformational administration of the construction organization.

\footnotetext{
* Corresponding author: GrigorevaSV2017@yandex.ru
} 


\section{Theory of transformational administration}

We will call transformational administration management of strategic stability of the construction organization, the representing nonlinear dynamic system.

The construction organization capable to develop, be enhanced harmoniously will be object of management.

Subject management strategic stability of development of the construction organization.

We will consider the principles of transformational administration: principle of duality, law of unity and interaction (fight) of contrasts, the principle of interrelation of quantitative and high-quality changes, the principle of double denial, the principle of golden ratio, balance (spatial stability), solvency in time (temporary stability).

The duality is shown that in a management system surely there are two opposite processes, for example chaos and an order.

The principle of interrelation of quantitative and high-quality changes provides existence of a measure which violation of border leads to change of a trajectory of organization development.

According to the principle of double denial the denials of the previous conditions of development repeated twice will lead to a condition with new forms, properties.

For determination of a zone of variability of system the principle of golden ratio is used.

The principle of solvency in time consists in maintenance of the ascending trend not only in short-term, but also in the long-term period of organization development.

The principle of balance is characterized by transport familiarity of the territory for ensuring access of subjects of managing to natural and human resources for the purpose of harmonization of production factors and the balanced development of system in the long term.

Transformational administration is shown in various forms.

Harmonious administration is an optimum static and dynamic coordination of stages of management of strategic stability of the construction organization.

The purpose of harmonious administration is creation of a harmonious management system strategic stability of the construction organization.

We will enter determination of a harmonious management system strategic stability of the construction organization.

Strategic stability of the construction organization we will call a harmonious management system such system in which a complex indicator of strategic stability of development belong to a zone of the stability located between two points of golden ratio $x_{1}=0,382$ and $x_{2}=0,618$ width of this subinterval constitutes 0,236 (fig. 1 ).

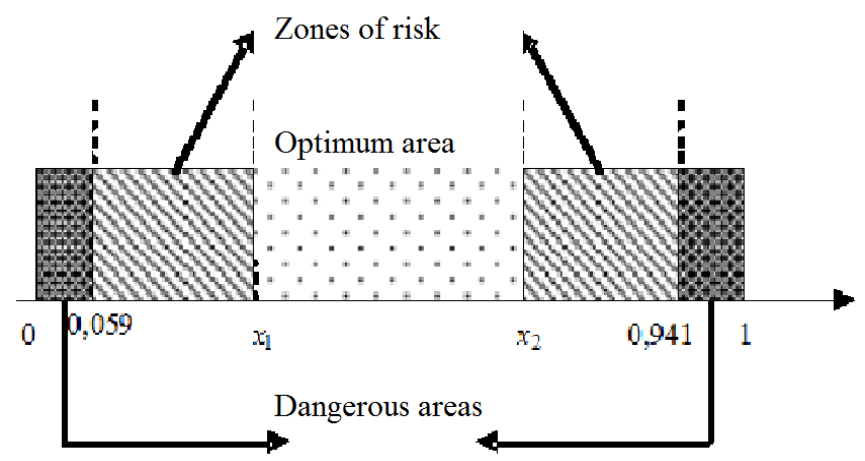

Fig. 1. Zones of variability of systems and processes: optimum area, dangerous areas and zones of risk of system 
The complex indicator of strategic stability of development is created on the basis of the systems of the indicators reflecting economic, technical, investment, social and nature protection aspects of organization activity The risk administration is a risk management on the basis of an integrated approach, an Integrated approach to risk management assumes a fixed risks assessment of strategic stability, handling and the analysis of results for the choice of priorities in acceptance of management decisions.

Risks of strategic stability include groups of risks temporary and spatial stability. These risks are shown in the long period of time and shan't be determined as discrete events. Outsourcing of nonbasic functions of the construction organization can eliminate risk sources that will provide strategic stability of development $[4,10]$.

Growth of a construction pulled for itself IT services [9]. Due to the policy announced by the government on import substitution interest in the Russian IT sector increased. Considerably interest in the software with an open code, the developed Russian specialists grew. In the conditions of transformation of an economic environment IT outsourcing gains steam every year. Major factors of the translation of nonbasic functions of the construction organization are: cost reduction on IT, concentration of the organization on the main functions, advanced technologies of IT provider, improvement of quality of customer service.

IT administration assumes dynamic management of strategic stability of the construction organization.

The purpose is increase in strategic stability of the organization due to implementation of the information environment. Information model of the organization is provided in the figure 2 .

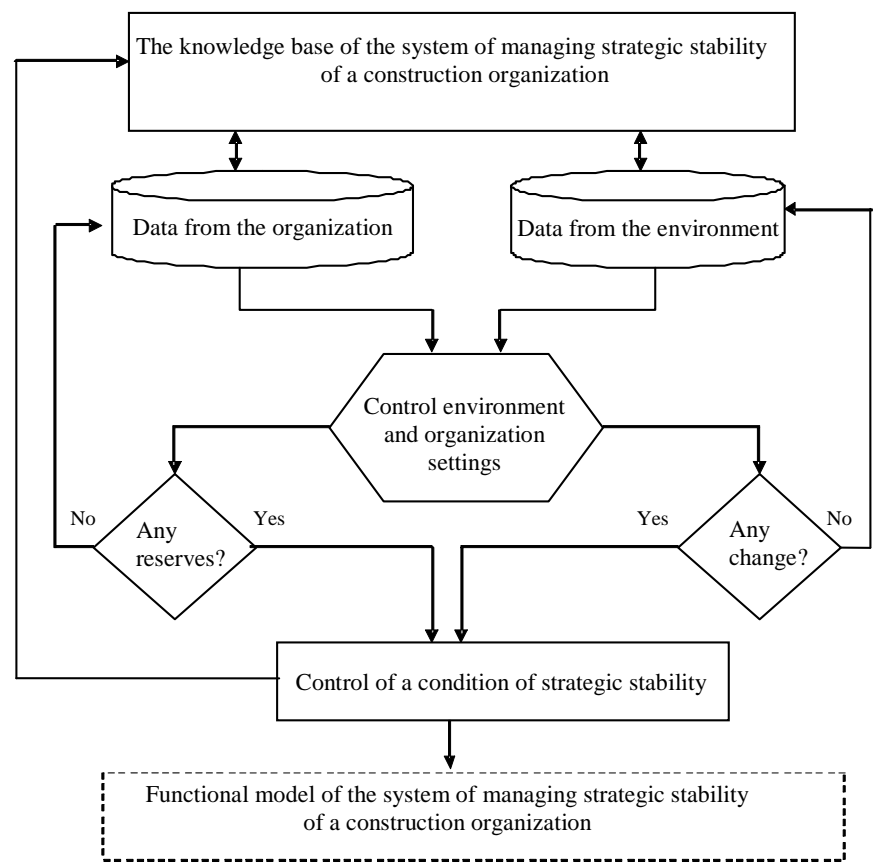

Fig. 2. Information model of the organization

The architecture of a management system strategic stability of the construction organization is the cornerstone of the theory of transformational administration. 
The architecture of a management system strategic stability of the construction organization represents model of the main arrangement and interrelations of internal parts of the organization.

The architecture of a management system strategic stability of the construction organization is a unity of the strategic determinants aimed at harmonious organization development in the short-term and long term.

In the conditions of transformation of an economic environment strategic stability of the construction organization is determined how quickly and effectively it can meet the modern changing market requirements.

Thus, the architecture of a management system strategic stability of the construction organization shows methods and methods of achievement of strategic stability of development.

There are various techniques of creation and assessment of architecture of the organization: Zakhman's technique; TOGAF technique; FEAF technique; Garther technique.

The architecture of a management system strategic stability of the 3D-model organization is under construction in three dimensions: axis of strategic designing (fig. 3), axis of strategic providing (fig. 4) and axis of strategic time (fig. 5).

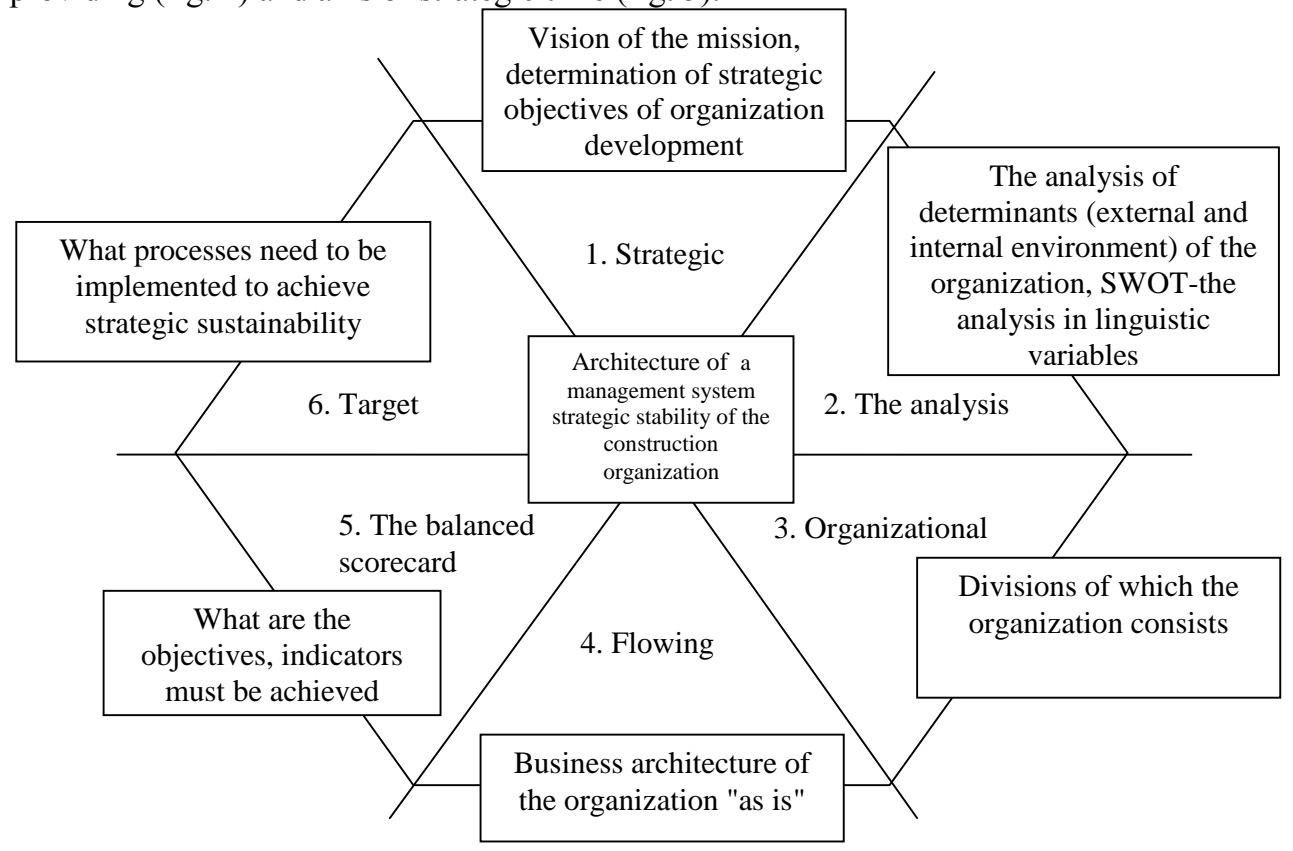

Fig. 3. Axis of strategic designing

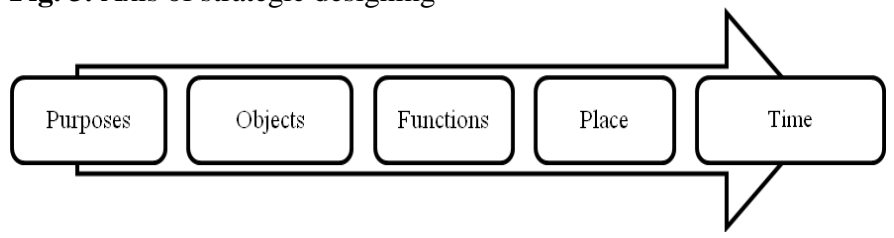

Fig. 4. Axis of strategic providing

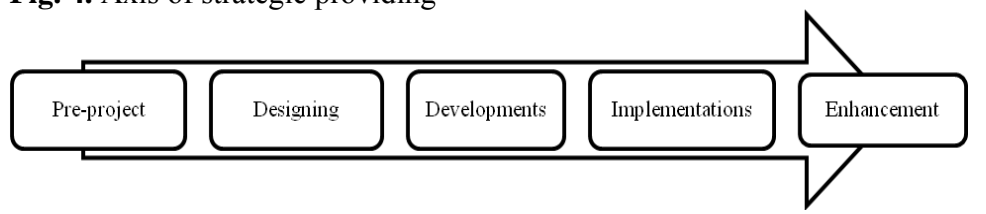

Fig. 5. Axis of strategic time 
The axis of strategic providing is projections (cuts) of the organization from the point of view of the fields of consideration (why that, as who where when):

the purposes $(\mathrm{T})$ (motivation of why the organization functions);

objects $(\mathrm{O})$ (that needs to be transformed);

functions $(\mathrm{F})$ (as transformation is performed);

the place $(\mathrm{P})$ (where transformation process is carried out);

time $(\mathrm{T})$ (when transformation process is carried out).

The axis of strategic time consists of the stages corresponding to stages of lifecycle of the organization: preproject, designing, developments, implementations, enhancement.

The architecture of a management system is given by strategic stability of the organization in the figure 6.

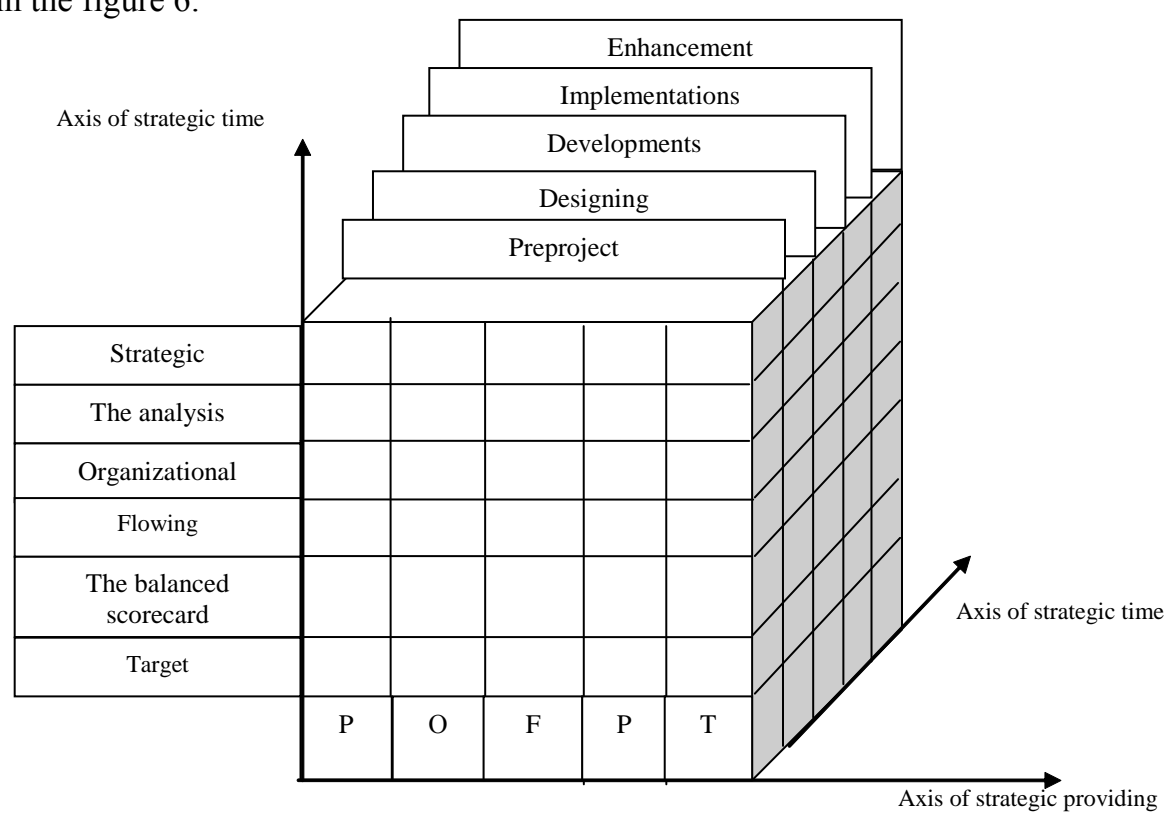

Fig. 5. Architecture of a management system strategic stability of the 3D-model organization

Thus, each of forms of transformational administration has the subject domain of management strategic stability of the construction organization.

\section{Conclusion}

Innovative development of the construction organization in conditions of transformation of an economic environment requires modern management, the system approach having multicomponent structure and assuming use. The developed theory of transformational administration develops the modern management theory and allows to prove the choice of management decisions when forecasting strategic stability of the construction organization.

\section{References}

1. A. Zbritskiy, Mekhanizmy upravleniya sotsial'no-ekonomicheskimi sistemami (innovatsionnyy aspekt) (Ekonomika stroitel'stva, 2014) 
2. S. Lochan, A. Chulaev Osobennosti postroeniya kontseptsii upravleniya innovatsionnoy deyatel'nost'yu krupnogo proizvodstvennogo kompleksa s ispol'zovaniem sistemy sbalansirovannykh pokazateley (Integral, 2010)

3. Z. Tuskaeva Problemy i perspektivy upravleniya tekhnicheskim potentsialom $v$ sfere stroitel'stva (Ustoychivoe razvitie gornykh territoriy,2011)

4. Charman. Projekt Risk Managemen,. Jnc., (1997)

5. Korol' S.P, Shuvalov A.A., Babenko E.V. Innovatsionnaya activities in the regional construction complex as a control object (Regional economy: theory and practicea, 2013)

6. Esetova A. M. Strategic aspects of efficiency rise of innovative activity at building enterprises (Innovation, 2006).

7. Sizova, E. I. Key directions of innovative activity in construction (Strategy of sustainable development of national and world economy: sat. international. scientific.prakt. Conf., 2015)

8. Kanapeckiene, L., Kaklauskas, A., Zavadskas, E. K., \& Seniut, M. Integrated knowledge management model and system for construction projects (Engineering Applications of Artificial Intelligence, 2010)

9. Kapliński, O. Information technology in the development of the Polish construction industry (Technological and Economic Development of Economy, 2009)

10. Turskis, Z., Gajzler, M., \& Dziadosz, A. Reliability, risk management, and contingency of construction processes and projects (Journal of Civil Engineering and Management, 2012)

11. Dziadosz, A., \& Kończak, A. Review of selected methods of supporting decisionmaking process in the construction industry (Archives of Civil Engineering, 2016).

12. Blayse, A., Manley, K. Key influences on construction innovation (Construction Innovation, 2004)

13. Jones, M., Saad, M. Managing innovation in construction. Thomas Telford, London. (2003) 